\title{
Technical feasibility of heating systems for two school districts in the town of Matera
}

\author{
Elisabetta Negro*, Nicola Cardinale, Gianluca Rospi \\ Università degli Studi della Basilicata, Dipartimento delle Culture Europee e del Mediterraneo, Via \\ Lazazzera snc, Matera, Italy
}

Email: ing.negroelisabetta@gmail.com

\begin{abstract}
The present work is focused on technical feasibility of heating system design of two School District situated in the town of Matera. This paper analyses three different heating system highlighting for each of them advantages and disadvantages respect energy covered and environmental impact. To design heating system we conducted a previous energy audit in dynamic conditions on School District. This previous step is necessary to define energy demand and the best strategies to improve energy efficiency of these structures.

Before to design heating system, we applied some envelope improvement on numerical model built with Design Builder software. In Fact, the school building which took part in School District has a high heat loss surface because they were built before the first Italian Law on energy efficiency. The heating system typologies considered in this study are: high temperature absorption heat pump integrated with a solar thermal system, high temperature electrical heat pump and cogeneration system. The first heating system typology has a great advantage in terms of primary energy because the conversion factor from natural gas to primary energy is equal to 1.05 . The second one, high temperature electrical heat pump, has a great energy efficiency respect to the first one ( $2.50 \mathrm{vs} 1.65)$ but, in term of primary energy, this system is not so convenient. In fact, the conversion factor from electricity to primary energy is equal to 1.95 . The third one, cogeneration system, has the advantages to cover not only heating request but also electric request of school district.
\end{abstract}

Keywords: Heat Pump Cogeneration Plant, Energy Audit, Energy Performance, Technical Feasibility.

\section{INTRODUCTION}

In the end years with the world population growth and the industrial development of the emergent countries have increased the world energy consumption.

In the last years, in the Italian Energy Balance the energy consumption for conditioning the buildings are increase; this has causes an increase to the use of fossil fuels.

The use of air conditioning systems makes necessary to find new renewable energy systems to produce the thermal and electricity energy.

Photovoltaic, solar thermal and wind energy are not continuous energy sources. These energy sources should be integrated with other energy sources, as the fossil fuels, to produce thermal and electric energy.

Today, the world energy generated is used very fast and the earth is not able to reactivate it and this compromised its sustainability. Moreover, the world energy resources decrease while energy needed by humanity increase.

Today, there are two ways to solve these problems: using and improving new renewable energy sources or to improve energy converting systems to use the energy in more efficiently and for much time, such as cogeneration system.
In [1] the authors analyse the environmental benefits and sustainability aspects of cogeneration systems and importance of those systems to the use of sustainable energy are underlined. The authors investigate on gas engine cogeneration system applied to a hospital, and they show the sustainability aspects of this cogeneration system.

Cogeneration systems, also called CHP (Combined Heat and Power), have some relevant environmental advantages. These systems have an increase of the efficiency and a decrease to fuel use compared to other conventional processes for thermal and electrical energy production.

Sustainability of cogeneration systems can be obtained using this heating system together with some renewable energy conversion systems like solar or heat pumps system. Cogeneration system can also be used together with different systems to save more energy. An example is given in [2] and named "multi-criteria optimization of a district cogeneration plant integrating a solid oxide fuel cell-gas turbine combined cycle, heat pumps and chillers". The conversion of heat into mechanical energy, which is the most complex transformation, is performed through a thermodynamic cycle: Rankine and Hirn cycles and the Brayton-Joule cycle in turbo-gas installations [3]. 
Another article [4] discusses various CHP technologies for household applications, taking into account different sources of heat energy such as combustion engines, Stirling engines, gas micro-turbines, ORC systems and thermos-photovoltaic devices. This article also addresses the economic aspects of the use of thermal energy storage (e.g. their economic viability).

In [5] the authors investigated a small CHP ORC system, which has been developed with the aim of using it in singlefamily houses. The electric and thermal power of the system is $2.5 \mathrm{kWe}$ and $25 \mathrm{kWth}$, respectively. A working prototype of the system was built. During the tests, the system's performance was evaluated based on the changes in such parameters as thermal load, flow rates of the working mediums and electrical load of the turbo generator. The results demonstrated that the prototype of the OCT system was able to operate correctly despite abrupt change in some of these parameters.

In [6] the authors present the results of the research on a CHP system comprising a vapour micro-turbine which was connected to the generator through the gear. Some researchers even go as far as pointing out how micro CHP systems may develop in the future, indicating their potential for use with thermal energy storages [7] or system expandability in order to use cogeneration of electricity and chill [8].

The cogeneration system uses the same fuel for a combined production and it uses primary energy more efficiently.

Generally, CHP systems are formed by a primary motor, a generator, a heat recovery system and electrical interconnections. The primary motor is any engine used for converting fuel into mechanical energy, the generator converts it into electric energy, while the heat recovery system collects and converts energy contained in the primary motor discharges into usable thermal energy.

As is stated in [9], combined production can increase the efficiency of use of fossil fuels more than $80 \%$. This permits lower costs and lower emissions of pollutants and greenhouse gases compared to separate electricity and heat productions.

Unlike power plants, CHP needs small systems that are able to generate heat and electricity for large structures (i.e. hospitals, hotels, etc.) or small urban centre.

In small-cogeneration system, combustion reaches savings up to $40 \%$ in the use of primary energy sources.

This paper is linked to work presented in AIGE-IIETA 2017 Conference [10] on which the authors investigate on a small-cogeneration system design for three school buildings in the town of Matera. The research analyses the economic advantage of this system. The authors designed CHP system by using the electricity request of the case studies analysed and its power is $90 \mathrm{kWel}$ with a pay-back time between three and four years.

The consequential evolution of an integrated system of cogeneration is tri-generation. It is possible, using a single source of primary energy, to obtain a production of electricity (or mechanical energy) and the heating for the cooling process.

\section{ENERGY AUDIT OF SCHOOL DISTRICTS}

The school districts are composed of three buildings for each district as is shown in Fig. 2 and 3. In this paper we used the energy audit conducted in dynamic regime using Energy Plus Code to analysed three heating system typologies at district level:
- High temperature absorption heat pump integrated with a solar thermal system;

- High temperature electrical heat pump;

- Cogeneration system.

We hypothesized to install a centralized system which serves every single building.

School Districts investigates took part of Horizon project, FESTA (Fostering local energy investments in the Province of Matera), won by Province of Matera in collaboration with University of Basilicata and Healthcare Centre in Matera (Matera ASL), owner of Policoro hospital.

School districts are located in Matera's town (Southern Italy). Geolocation of School Districts is shown in Figure 2.
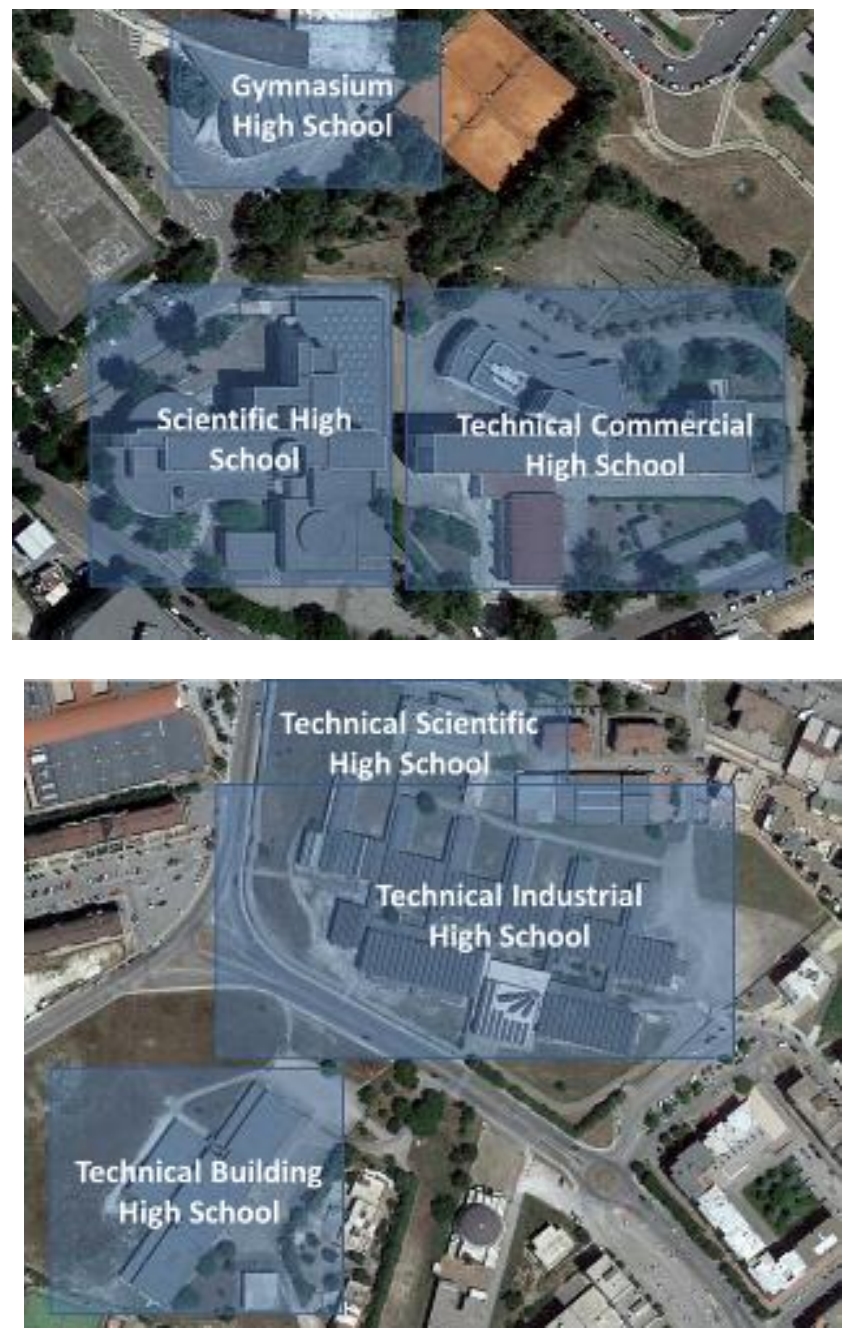

Figure 1. School district 1 and 2 geolocations

School Districts are composed of structures built before the first Italian law on energy efficiency $[11,12]$ therefore they are characterized by a high heat loss of envelope.

District n. 1 is composed by:

- Gymnasium High School (1966): It was built is a 6-floor building. Opaque envelope is in reinforced concrete and external walls are in plastered brick. Transparent envelope is composed of single-glazed window. (Fig. 3)

- Scientific High School (1971): it is a 4-floor building with opaque in reinforced concrete structure with external facing walls and brick-concrete floors. Transparent envelope is 
composed of a single-glazed with metal frame without thermal break. (Fig. 4)

- Technical Commercial High School (1961): it is a 5-floor building with opaque envelope composed of a reinforced concrete structure with external walls in plastered brick. Transparent envelope is composed of a single-glazed with metal frame without thermal break. (Fig. 5)

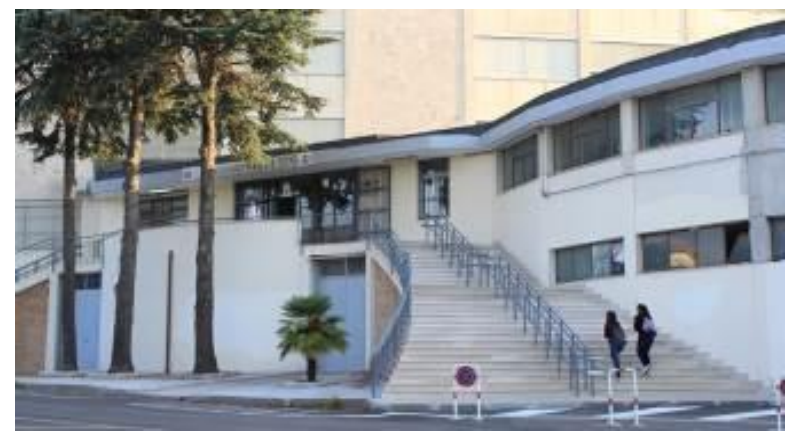

Figure 2. Gymnasium high school

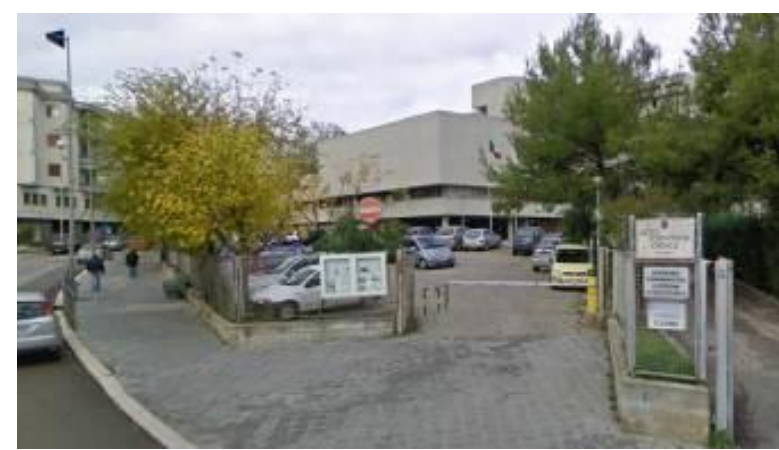

Figure 3. Scientific high school

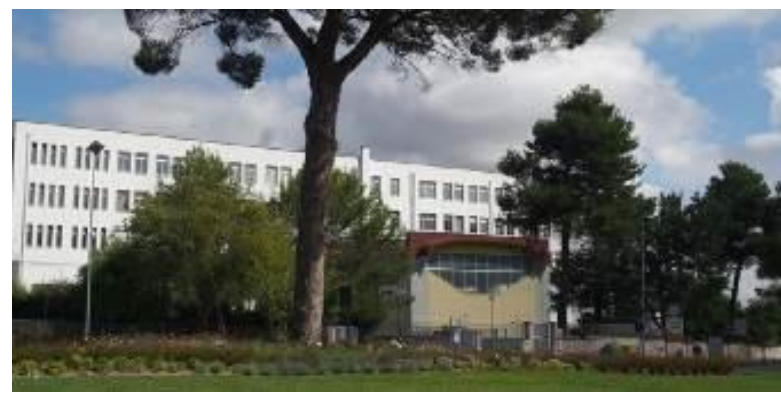

Figure 4. Technical commercial high school

District n. 2 is composed by:

- Technical Industrial High School (1987): It was built is a 2floor building. Opaque envelope is in reinforced concrete and external walls are in concrete. Transparent envelope is composed of single-glazed window. (Fig. 6)

- Technical Scientific High School (2000): it is a 2-floor building with opaque in reinforced concrete structure with external facing walls with air gaps and brick-concrete floors. Transparent envelope is composed of a double-glazed with metal frame without thermal break. (Fig. 7)

- Technical Building High School (1981): it is a 5-floor building with opaque envelope composed with prefabricated panels and ceilings in brick-cement. Transparent envelope is composed of a double-glazed with metal frame without thermal break. (Fig. 8)

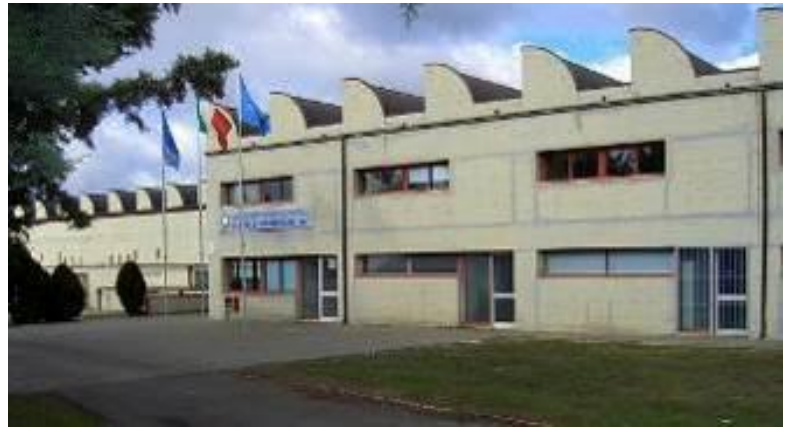

Figure 5. Technical industrial high school

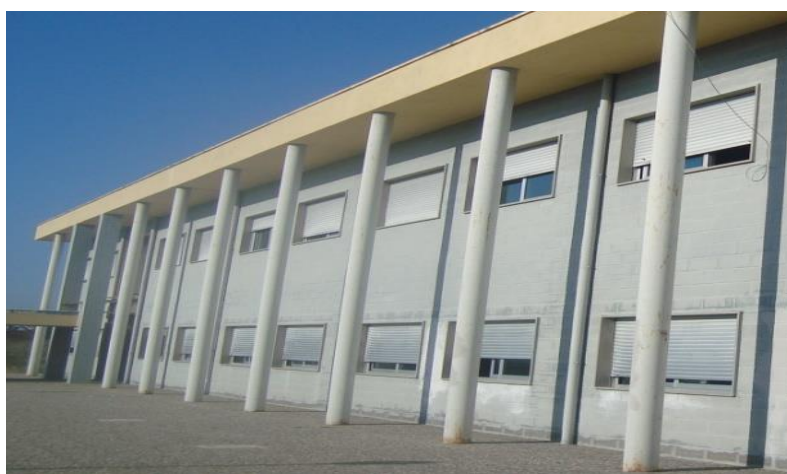

Figure 6. Technical scientific high school

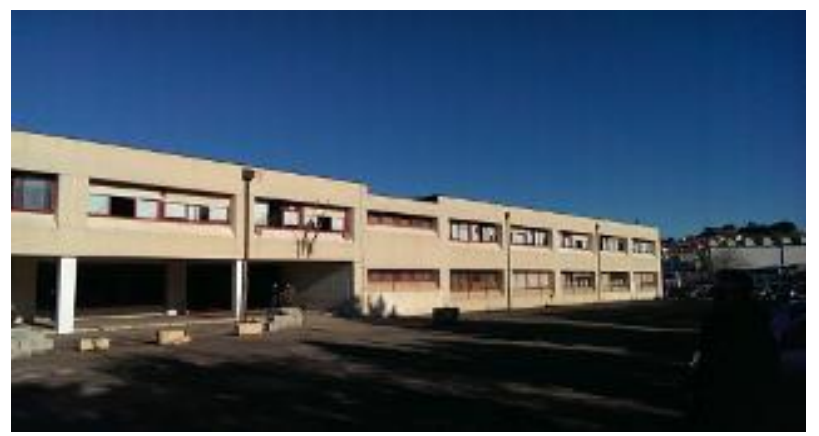

Figure 7. Technical building high school

Thermal characteristic of envelope is shown in Table 1 in terms of thermal transmittance measured in situ by using ISO 9869 [13] for vertical opaque envelope. We measured thermal flux and indoor and outdoor surface temperature of wall for five days and then we calculated the thermal conductance by using the average progressive method [14]. Instead of the horizontal surface thermal transmittance we used the UNI EN ISO 6946:2008 [15]; while for transparent envelope thermal transmittance we used UNI EN ISO 10077 $1-2$ [16].

After performing the geometric survey of the buildings, we divided the buildings into different thermal zones. This subdivision was performed according to the different characteristics of the envelopes that characterize the building and on a different distribution and type of thermal system.

Another parameter necessary for modelling building-plant system is related to the energy consumptions (thermal and electric). Knowing energy consumption after a monitoring campaign (2013 -2015), the authors set building-plant system for each structure. 
Table 1. Thermal transmittance of buildings envelope of School District 1 and School District 2

\begin{tabular}{|c|c|c|c|c|}
\hline \multicolumn{2}{|r|}{ Building } & $\begin{array}{c}\text { External } \\
\text { walls } \\
\mathrm{U} \\
{\left[\mathrm{W} / \mathrm{m}^{2} \mathrm{~K}\right]}\end{array}$ & $\begin{array}{c}\text { Coverage } \\
\mathrm{U} \\
{\left[\mathrm{W} / \mathrm{m}^{2} \mathrm{~K}\right]}\end{array}$ & $\begin{array}{c}\text { Windows } \\
\mathrm{U} \\
{\left[\mathrm{W} / \mathrm{m}^{2} \mathrm{~K}\right]}\end{array}$ \\
\hline \multirow{3}{*}{ 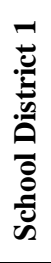 } & $\begin{array}{c}\text { Gymnasium High } \\
\text { School }\end{array}$ & 1.54 & 1.50 & 5.78 \\
\hline & $\begin{array}{c}\text { Scientific High } \\
\text { School }\end{array}$ & 2.54 & 2.21 & 5.78 \\
\hline & $\begin{array}{c}\text { Technical } \\
\text { Commercial High } \\
\text { School } \\
\end{array}$ & 2.06 & 1.60 & 5.78 \\
\hline \multirow{3}{*}{ 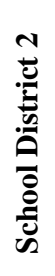 } & $\begin{array}{l}\text { Technical Industrial } \\
\text { High School }\end{array}$ & 2.54 & 2.88 & 5.78 \\
\hline & $\begin{array}{c}\text { Technical Scientific } \\
\text { High School }\end{array}$ & 0.54 & 0.58 & 3.09 \\
\hline & $\begin{array}{l}\text { Technical Building } \\
\text { High School }\end{array}$ & 0.83 & 0.89 & 4.03 \\
\hline
\end{tabular}

In the Design Builder model, we considered the official hours of operation provided for the specific climate zone defined by Italian Law. In Matera the heating period goes from November 1 to April 15 for a maximum of 12 hours a day. For all buildings the heating system is characterized by condensing boilers with radiators as emission terminal and cooling system is no present (Table 2).

Table 2. Heating system characteristic of School District 1 and School District 2

\begin{tabular}{|c|c|c|c|}
\hline & Building & Heating system & $\begin{array}{c}\text { Installed } \\
\text { thermal } \\
\text { power }\end{array}$ \\
\hline $\bar{E}$ & $\begin{array}{c}\text { Gymnasium High } \\
\text { School }\end{array}$ & $\begin{array}{l}\text { Condensing boiler with } \\
\text { radiators }\end{array}$ & 610 \\
\hline 䓂 & Scientific High School & $\begin{array}{l}\text { Condensing boiler with } \\
\text { radiators }\end{array}$ & 1075 \\
\hline ᄅ̊ & $\begin{array}{c}\text { Technical } \\
\text { Commercial High } \\
\text { School }\end{array}$ & $\begin{array}{l}\text { Condensing boiler with } \\
\text { radiators }\end{array}$ & 928 \\
\hline$\stackrel{\sim}{\stackrel{N}{g}}$ & $\begin{array}{l}\text { Technical Industrial } \\
\text { High School }\end{array}$ & $\begin{array}{l}\text { Condensing boiler with } \\
\text { radiators }\end{array}$ & 2670 \\
\hline$\frac{\bar{n}}{0}$ & $\begin{array}{l}\text { Technical Scientific } \\
\text { High School }\end{array}$ & $\begin{array}{l}\text { Condensing boiler with } \\
\text { radiators }\end{array}$ & 390 \\
\hline ֻँّ & $\begin{array}{l}\text { Technical Building } \\
\text { High School }\end{array}$ & $\begin{array}{l}\text { Condensing boiler with } \\
\text { radiators }\end{array}$ & 980 \\
\hline
\end{tabular}

In the following tables 3 and 4, we summarized the energy consumption of heating system and electrical system.

Moreover Table 5 and 6 show the activity parameters used for school districts.
Table 3. Natural gas consumptions of School District 1 and School District 2

\begin{tabular}{|c|c|c|c|}
\hline \multirow{2}{*}{\multicolumn{2}{|c|}{ Building }} & \multicolumn{2}{|c|}{ Heating system request } \\
\hline & & Scm/year & kWhth/year \\
\hline \multirow{3}{*}{ 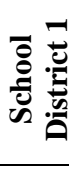 } & Gymnasium High School & 26676 & 280098 \\
\hline & Scientific High School & 36881 & 387251 \\
\hline & $\begin{array}{c}\text { Technical Commercial High } \\
\text { School }\end{array}$ & 50461 & 529841 \\
\hline \multirow{3}{*}{ 党: } & $\begin{array}{c}\text { Technical Industrial High } \\
\text { School }\end{array}$ & 119887 & 1258814 \\
\hline & $\begin{array}{c}\text { Technical Scientific High } \\
\text { School }\end{array}$ & 10727 & 112634 \\
\hline & $\begin{array}{c}\text { Technical Building High } \\
\text { School }\end{array}$ & 35259 & 370220 \\
\hline
\end{tabular}

Table 4. Electric energy consumptions of School District 1 and School District 2

\begin{tabular}{|c|c|c|}
\hline \multicolumn{2}{|r|}{ Building } & $\begin{array}{l}\text { Electric system } \\
\text { request }\end{array}$ \\
\hline 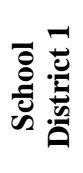 & $\begin{array}{l}\text { Gymnasium High School } \\
\text { Scientific High School } \\
\text { Technical Commercial High School }\end{array}$ & $\begin{array}{l}39252 \\
80270 \\
72339\end{array}$ \\
\hline 党 & $\begin{array}{l}\text { Technical Industrial High School } \\
\text { Technical Scientific High School } \\
\text { Technical Building High School }\end{array}$ & $\begin{array}{r}178419 \\
74383\end{array}$ \\
\hline
\end{tabular}

Table 5. Activity parameters - District 1

\begin{tabular}{|c|c|c|c|c|c|c|}
\hline District 1 & 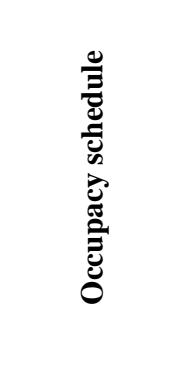 & 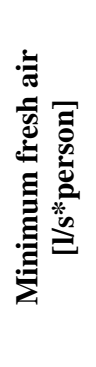 & 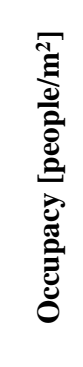 & 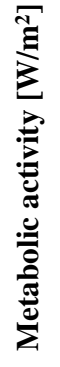 & 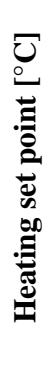 & 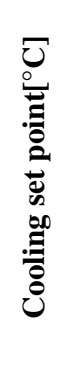 \\
\hline $\begin{array}{c}\text { Gymnasium High } \\
\text { School }\end{array}$ & $15 / 09-15 / 07$ & 1 & 0.010 & 0.7 & 20 & 28 \\
\hline $\begin{array}{c}\text { Scientific High } \\
\text { School } \\
\text { Technical }\end{array}$ & $15 / 09-15 / 07$ & 1 & 0.011 & 0.7 & 20 & 28 \\
\hline $\begin{array}{c}\text { Commercial High } \\
\text { School }\end{array}$ & 15/09-15/07 & 1 & 0.014 & 0.7 & 20 & 28 \\
\hline
\end{tabular}


Table 6. Activity parameters - District 2

\begin{tabular}{|c|c|c|c|c|c|c|}
\hline District 2 & 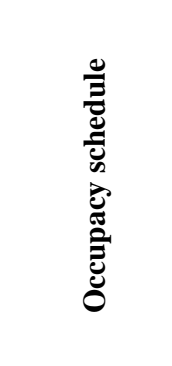 & 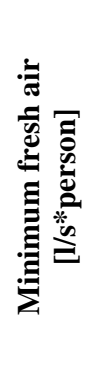 & 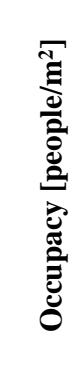 & 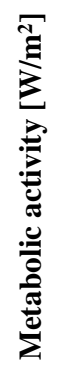 & 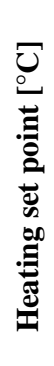 & 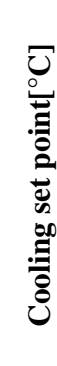 \\
\hline $\begin{array}{c}\text { Technical } \\
\text { Industrial High } \\
\text { School } \\
\text { Technical }\end{array}$ & $15 / 09-15 / 07$ & 1 & 0.015 & 0.7 & 20 & 28 \\
\hline $\begin{array}{c}\text { Scientific High } \\
\text { School }\end{array}$ & $15 / 09-15 / 07$ & 1 & 0.010 & 0.7 & 22 & 28 \\
\hline $\begin{array}{l}\text { Technical Building } \\
\text { High School }\end{array}$ & $15 / 09-15 / 07$ & 1 & 0.010 & 0.7 & 20 & 8 \\
\hline
\end{tabular}

These data were used to model and to set the dynamic model by using Design Builder software based on Energy Plus code [17].

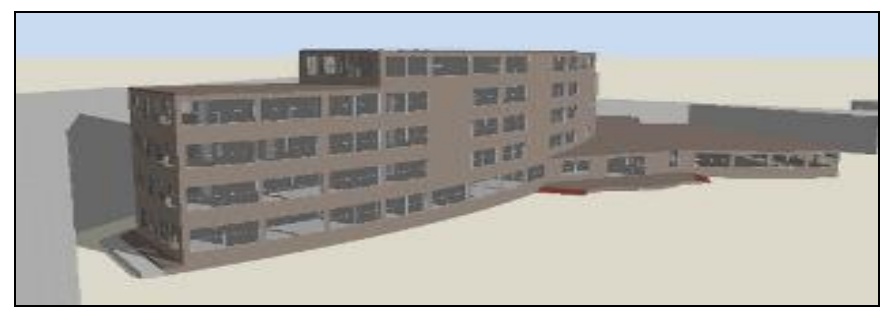

Figure 8 - Design builder model of Gymnasium High School

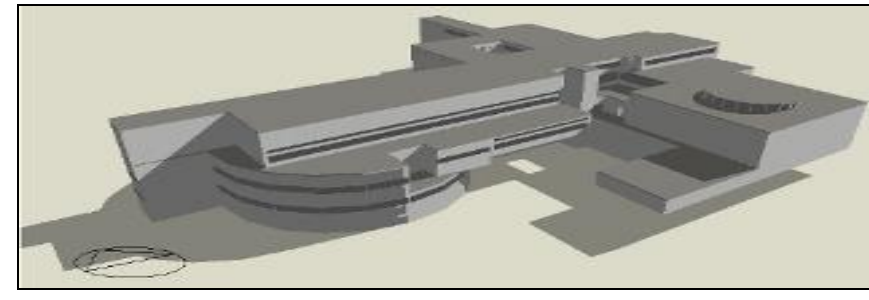

Figure 9 - Design builder model of Scientific High School

Figure 10. Design builder model of Technical Commercial High School

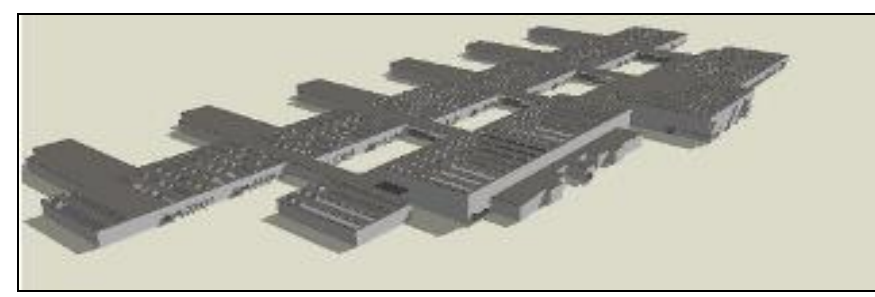

Figure 11 - Design builder model of Technical Industrial High School

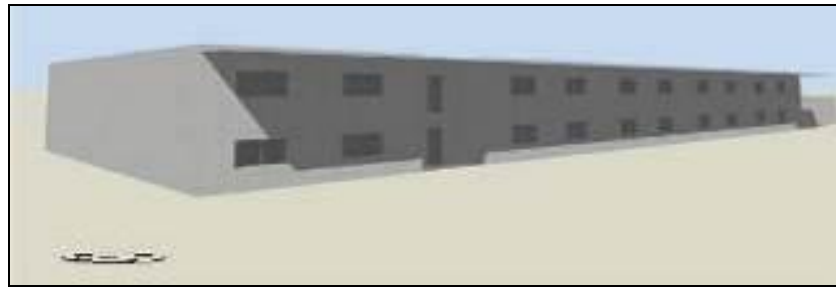

Figure 12. Design builder model of Technical Scientific High School

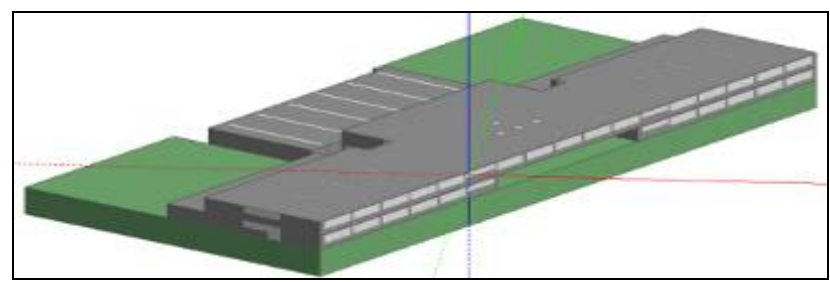

Figure 13 - Design builder model of Technical Building High School

Data shown in table 7 and table 8 are necessary to understand the energy request of the entire district and in order to design the different heating system typologies.

Calibration of the model was carried out on natural gas consumption.

Table 7. Calibration model of School District 1

\begin{tabular}{c|ccc}
\multirow{2}{*}{ School District 1 } & \multicolumn{3}{|c}{ Heating consumption } \\
& Measured & Simulated & $\Delta$ \\
& scm/year & scm/year & $\%$ \\
\hline Gymnasium High School & 26676 & 24782 & $7.1 \%$ \\
Scientific High School & 49871 & 48588 & $2.6 \%$ \\
Technical Commercial High School & 36881 & 33482 & $9.2 \%$ \\
\hline Total & 113428 & 106852 &
\end{tabular}

Table 8. Calibration model of School District 2

\begin{tabular}{c|ccc} 
& \multicolumn{3}{|c}{ Heating consumption } \\
School District 2 & $\begin{array}{c}\text { Measured } \\
\text { scm/year }\end{array}$ & $\begin{array}{c}\text { Simulated } \\
\text { scm/year }\end{array}$ & $\%$ \\
\hline $\begin{array}{c}\text { Technical Industrial } \\
\text { High School } \\
\text { Technical Scientific } \\
\text { High School }\end{array}$ & 119887 & 117695 & $1.8 \%$ \\
$\begin{array}{c}\text { Technical Building High } \\
\text { School }\end{array}$ & 10727 & 10528 & $1.9 \%$ \\
\hline Total & 165873 & 34611 & $1.8 \%$ \\
\hline & & 162834 &
\end{tabular}

\section{TECHNICAL ANALYSIS OF DIFFERENT HEATING SYSTEM TYPOLOGIES}

As is stated in $\$ 2$ of this paper, all school building is characterized by a high heat loss surface. Before analyzing the heating system improvement, we performed some building envelope improvements in order to respect Italian 
minimum standard [18]. Building envelope improvements are described in following:

- Insulation of walls with inner coat: a plasterboard sheet thickness mm 10 coupled to an insulating layer consisting of panel hemp fibre with thermal conductivity $\lambda$ equal to 0.030 W/mK (Fig. 15);

- Insulation of flat roof with inner coat: a plasterboard sheet thickness $\mathrm{mm} 10$ coupled to an insulating layer consisting of panel hemp fibre with thermal conductivity $\lambda$ equal to 0.030 W/mK (Fig. 16);

- Replacement of the windows: existent window frames replaced by PVC double glazed windows with low-emissivity 4/8/4 with argon gas cavity $8 \mathrm{~mm}$ (Fig. 17).

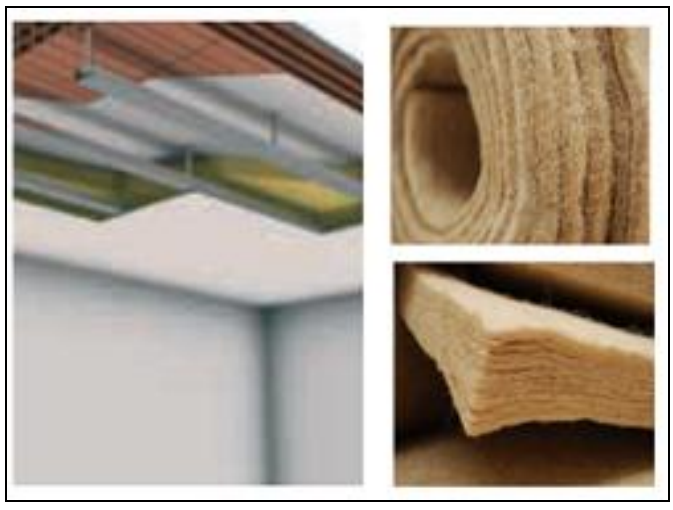

Figure 14. Inner insulation of roof with kenaf fibre

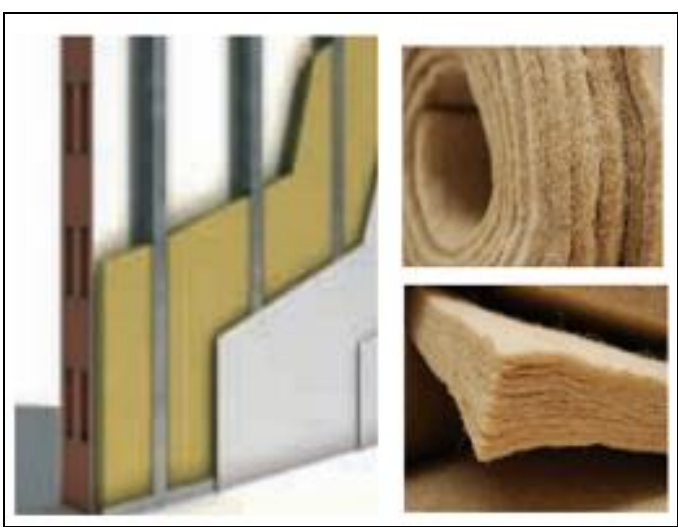

Figure 15. Inner insulation of wall with kenaf fibre

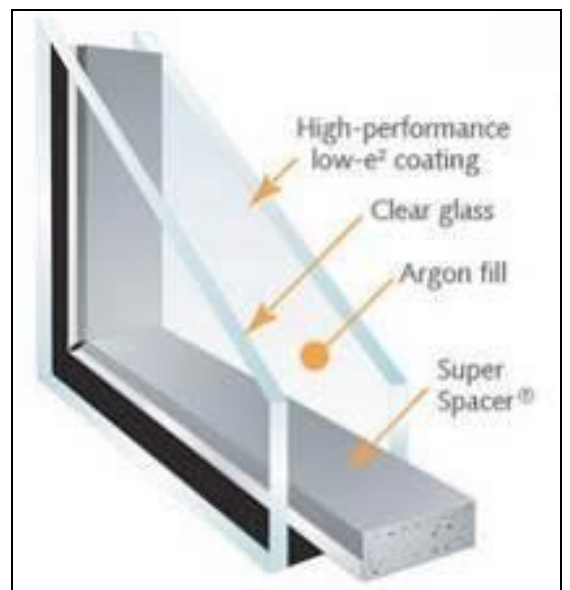

Figure 16. Double glazed window with a thermal transmittance $\mathrm{U}=1,717 \mathrm{~W} / \mathrm{m}^{2} \mathrm{~K}$
These improvements are necessary to respect Italian minimum standard, to reduce energy consumption and to increase savings in economic and environmental.

In table below, it is shown thermal transmittance " $U$ " of the envelope with the insulation thickness "s" used.

Table 9. Characteristic of improvements for School District 1

\begin{tabular}{l|cc|cc|c}
\multicolumn{1}{c|}{$\begin{array}{c}\text { School } \\
\text { District 1 }\end{array}$} & \multicolumn{2}{|c|}{ Insulation of walls } & \multicolumn{2}{|c|}{$\begin{array}{c}\text { Insulation of flat } \\
\text { roof }\end{array}$} & $\begin{array}{c}\text { Replace } \\
\text { ment of } \\
\text { the } \\
\text { windows }\end{array}$ \\
\hline & $\begin{array}{c}\mathrm{s} \\
{[\mathrm{cm}]}\end{array}$ & $\begin{array}{c}\mathrm{U} \\
{\left[\mathrm{W} / \mathrm{m}^{2} \mathrm{~K}\right]}\end{array}$ & $\begin{array}{c}\mathrm{s} \\
{[\mathrm{cm}]}\end{array}$ & $\begin{array}{c}\mathrm{U} \\
{\left[\mathrm{W} / \mathrm{m}^{2} \mathrm{~K}\right]}\end{array}$ & $\begin{array}{c}\mathrm{U} \\
{\left[\mathrm{W} / \mathrm{m}^{2} \mathrm{~K}\right]}\end{array}$ \\
\hline $\begin{array}{l}\text { Gymnasium } \\
\text { High School } \\
\text { Scientific }\end{array}$ & 8 & 0,30 & 10 & 0,25 & 1,71 \\
$\begin{array}{l}\text { High School } \\
\text { Technical } \\
\text { Commercial } \\
\text { High School }\end{array}$ & 9 & 0,29 & 11 & 0,24 & 1,71 \\
\hline
\end{tabular}

Table 10. Characteristic of improvements for School District 2

\begin{tabular}{|c|c|c|c|c|c|}
\hline \multirow[t]{2}{*}{$\begin{array}{c}\text { School } \\
\text { District } 2\end{array}$} & \multicolumn{2}{|c|}{ Insulation of walls } & \multicolumn{2}{|c|}{$\begin{array}{l}\text { Insulation of flat } \\
\text { roof }\end{array}$} & \multirow{2}{*}{$\begin{array}{c}\begin{array}{c}\text { Replace } \\
\text { ment of } \\
\text { the } \\
\text { windows }\end{array} \\
\mathrm{U} \\
{\left[\mathrm{W} / \mathrm{m}^{2} \mathrm{~K}\right]}\end{array}$} \\
\hline & $\begin{array}{c}\mathrm{s} \\
{[\mathrm{cm}]}\end{array}$ & $\begin{array}{c}\mathrm{U} \\
{\left[\mathrm{W} / \mathrm{m}^{2} \mathrm{~K}\right]}\end{array}$ & $\begin{array}{c}\mathrm{s} \\
{[\mathrm{cm}]}\end{array}$ & $\begin{array}{c}\mathrm{U} \\
{\left[\mathrm{W} / \mathrm{m}^{2} \mathrm{~K}\right]}\end{array}$ & \\
\hline $\begin{array}{l}\text { Technical } \\
\text { Industrial } \\
\text { High School }\end{array}$ & 9 & 0,31 & 11 & 0,25 & 1,71 \\
\hline $\begin{array}{l}\text { Technical } \\
\text { Scientific } \\
\text { High School }\end{array}$ & 4 & 0,31 & 7 & 0,25 & 1,71 \\
\hline $\begin{array}{c}\text { Technical } \\
\text { Building } \\
\text { High School }\end{array}$ & 6 & 0,31 & 9 & 0,24 & 1,71 \\
\hline
\end{tabular}

The interventions described in previous tables have been applied and simulated in numerical models in order to evaluate the energy savings obtainable with a total requalification on the envelope.

To perform the heating system improvement, we used the energy simulated consumption after envelope improvements.

Table 11 shows the percentage of energy saving of the two School Districts.

Table 11. Percentage of savings and natural gas consumption after intervention on envelope (School District 1)

\begin{tabular}{c|ccc} 
School District & $\begin{array}{c}\text { Energy } \\
\text { consumption } \\
\text { without envelope } \\
\text { interventions } \\
\mathrm{kWh} / \mathrm{year}\end{array}$ & $\begin{array}{c}\text { Energy } \\
\text { consumption } \\
\text { after envelope } \\
\text { interventions } \\
\mathrm{kWh} / \mathrm{year}\end{array}$ & $\begin{array}{c}\text { Energy } \\
\text { savings }\end{array}$ \\
\hline $\mathbf{1}$ & 1197190 & 238046 & $\%$ \\
$\mathbf{2}$ & 1741668 & 598164 & $65 \%$
\end{tabular}

For School District 1 the energy saving, express in percentage, is higher than School District 2. The reason of this is due to the higher heat loss surface of envelope for all buildings which composed School District 1 .

For heating system improvements three solutions were analysed for both School Districts: 
- High temperature absorption heat pump integrated with a solar thermal system;

- High temperature electrical heat pump;

- Cogeneration system

\subsection{High temperature absorption heat pump integrated} with a solar thermal system

The absorption heat pump system studied supplies the thermal energy to the School District.

This heating system must guarantee an energy request of $22671 \mathrm{scm} /$ year for School District 1 and an energy request $56968 \mathrm{scm} /$ year for School District 2.

This heating system is built of a high temperature absorption heat pump integrated with a solar thermal system. The heating system includes the replacement of thermostatic valves which allows benefiting from any free heat gains. They are adjustment systems that vary the flow of food to the heating body as a function of the power required by the environment.

The replacement of old thermal power station with a heat absorption modulating condensing "air to water" gas powered pump (natural gas or LPG) + air source renewable energy with G.U.E. $165 \%$ reduces the consumption of natural gas for heating to the same installed power and contributes $39.4 \%$ to the share of renewable energy. In order to cover with RES $50 \%$ total consumption for heating, cooling and DHW required by law since 2017 , it will install a solar thermal system. (Fig. 18)

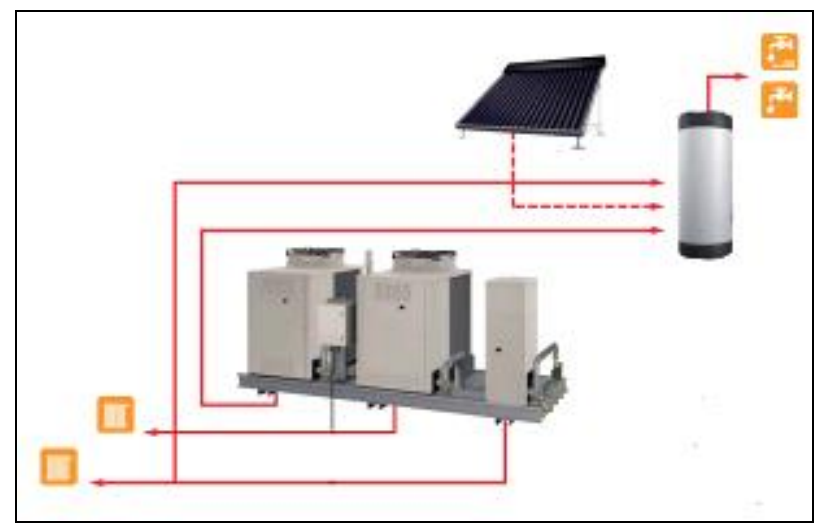

Figure 17 - High temperature absorption heat pump integrated with a solar thermal system

Table 12. Energy efficiency of actual heating system power and high temperature absorption heat pump power (School District 1)

\begin{tabular}{|c|c|c|c|c|}
\hline \multirow{2}{*}{ School District 1} & \multicolumn{2}{|c|}{$\begin{array}{l}\text { Actual heating } \\
\text { system }\end{array}$} & \multicolumn{2}{|c|}{$\begin{array}{l}\text { High temperature } \\
\text { absorption heat } \\
\text { pump }\end{array}$} \\
\hline & $\begin{array}{c}\text { Power } \\
\text { kW }\end{array}$ & $\eta$ & $\begin{array}{c}\text { Power } \\
\text { kW }\end{array}$ & $\eta$ \\
\hline Gymnasium High School & 610 & 0.65 & 274 & 1.65 \\
\hline Scientific High School & 1075 & 0.74 & 534 & 1.65 \\
\hline $\begin{array}{c}\text { Technical Commercial } \\
\text { High School }\end{array}$ & 928 & 0.60 & 294 & 1.65 \\
\hline Total & 2613 & 0.66 & 1202 & 1.65 \\
\hline
\end{tabular}

Thanks to the installation of a new heating system we obtained a high reduction of power necessary for the entire school districts. In particularly the energy power needs for School District 1 is equal to $1202 \mathrm{~kW}$ respect to $2613 \mathrm{~kW}$ as reported in Table 12 (total energy power for three school building that compose School District 1).

For School District 2 the energy power need is equal to $1731 \mathrm{~kW}$ respect to $4040 \mathrm{~kW}$ as reported in Table 13(total energy power for three school building that compose School District 1).

Table 13. Energy efficiency of actual heating system power and high temperature absorption heat pump power (School District 2)

\begin{tabular}{|c|c|c|c|c|}
\hline \multirow[t]{2}{*}{ School District 2} & \multicolumn{2}{|c|}{$\begin{array}{l}\text { Actual } \\
\text { heating } \\
\text { system }\end{array}$} & \multicolumn{2}{|c|}{$\begin{array}{c}\text { High } \\
\text { temperature } \\
\text { absorption } \\
\text { heat pump }\end{array}$} \\
\hline & $\begin{array}{c}\text { Power } \\
\mathrm{kW}\end{array}$ & $\eta$ & $\begin{array}{c}\text { Power } \\
\mathrm{kW}\end{array}$ & $\eta$ \\
\hline Technical Industrial High School & 2670 & 0.64 & 1036 & 1.65 \\
\hline Technical Scientific High School & 390 & 0.83 & 196 & 1.65 \\
\hline Technical Building High School & 980 & 0.84 & 499 & 1.65 \\
\hline Total & 4040 & 0.77 & 1731 & 1.65 \\
\hline
\end{tabular}

The thermal solar system integrated, considering a panel production, is shown in table 14 and 15 .

Table 14. Thermal solar system of School District 1

\begin{tabular}{c|cc} 
School District 1 & $\begin{array}{c}\text { FER Residual to } \\
\text { be Guaranteed } \\
\text { kWh }\end{array}$ & $\mathbf{N}^{\circ}$ panel \\
\hline Gymnasium High School & 3221 & 4 \\
$\begin{array}{c}\text { Scientific High School } \\
\text { Technical Commercial } \\
\text { High School }\end{array}$ & 11616 & 16 \\
\hline Total & 8634 & 12 \\
\hline & $\mathbf{2 3 4 7 1}$ & $\mathbf{3 2}$
\end{tabular}

Table 15. Thermal solar system of School District 2

\begin{tabular}{c|cc} 
School District 2 & $\begin{array}{c}\text { FER Residual to } \\
\text { be Guaranteed } \\
\text { kWh }\end{array}$ & $\mathbf{N}^{\circ}$ panel \\
\hline Technical Industrial High & 54185 & 74 \\
$\begin{array}{c}\text { School } \\
\text { Technical Scientific High } \\
\begin{array}{c}\text { School } \\
\text { Technical Building High } \\
\text { School }\end{array}\end{array}$ & 4328 & 6 \\
\hline Total & 6480 & 9 \\
\hline
\end{tabular}

The installation of a high temperature absorption heat pump integrated with a solar thermal system produces a high energy saving.

The heating system energy savings of two School Districts is reported in table 16

The heating system actions have an added improvement of $44 \%$ for School District 1 and of $38 \%$ for School District 2.

The total energy savings of envelope and heating system improvement respect to the actual situation (nothing improvements) are $89 \%$ for School District 1 and $78 \%$ for School District 2. 
Table 16. Energy saving after heating system improvement

\begin{tabular}{c|c|c|c}
$\begin{array}{c}\text { School } \\
\text { district }\end{array}$ & $\begin{array}{c}\text { Energy } \\
\text { consumption } \\
\text { after envelope } \\
\text { interventions }\end{array}$ & $\begin{array}{c}\text { Energy } \\
\text { consumption } \\
\text { after envelope } \\
\text { and heating } \\
\text { system } \\
\text { improvement } \\
\mathrm{kWh} / \text { year }\end{array}$ & $\begin{array}{c}\text { Energy } \\
\text { savings }\end{array}$ \\
\hline $\mathbf{1}$ & $\mathrm{kWh} /$ year & 133791 & $\%$ \\
$\mathbf{2}$ & 238046 & 371389 & 38
\end{tabular}

\subsection{High temperature electrical heat pump}

The second hypothesis is the installation of a unique high temperature electrical heat pump.

Even this system supplies the thermal energy to the School District.

As the heating system described in paragraph 3.1, also this heating system must guarantee an energy request of 22671 $\mathrm{scm} /$ year for School District 1 and an energy request 56968 $\mathrm{scm} /$ year for School District 2.

The electric heat pump used is an air-water heat pump. This machine allows the production of chilled water during the summer and high temperature hot water, up to $65^{\circ} \mathrm{C}$ during the winter.

This system uses electric power to generate heat and needs of a high request of electric energy with an high management costs for school districts.

This system is not convenient from environmental point of view because the electric energy has a conversion factor of 1.95 respects 1.05 of natural gas in primary energy terms.

The installation of this heating system typology allows to reduce the power necessary for the entire school districts. In particularly the power need for School District 1 is equal to $700 \mathrm{~kW}$ respect to $2613 \mathrm{~kW}$ as reported in Table 17 (total energy power for three school building that compose School District 1).

Table 17. Energy efficiency of actual heating system power and high temperature electrical heat pump power (School

\section{District 1)}

\begin{tabular}{c|cccc} 
& \multicolumn{3}{|c}{$\begin{array}{c}\text { Actual heating } \\
\text { system }\end{array}$} & $\begin{array}{c}\text { High temperature } \\
\text { electrical heat } \\
\text { pump }\end{array}$ \\
School District 1 & $\begin{array}{c}\text { Power } \\
\mathrm{kW}\end{array}$ & $\eta$ & $\begin{array}{c}\text { Power } \\
\mathrm{kW}\end{array}$ & $\eta$ \\
\hline $\begin{array}{c}\text { Gymnasium High School } \\
\text { Scientific High School }\end{array}$ & 610 & 0.65 & 159 & 2.50 \\
$\begin{array}{c}\text { Technical Commercial } \\
\text { High School }\end{array}$ & 928 & 0.60 & 223 & 2.50 \\
\hline Total & $\mathbf{2 6 1 3}$ & $\mathbf{0 . 6 6}$ & $\mathbf{7 0 0}$ & $\mathbf{2 . 5 0}$
\end{tabular}

For School District 2 the power need is equal to $1142 \mathrm{~kW}$ respect to $4040 \mathrm{~kW}$ as reported in Table 18 (total energy power for three school building that compose School District $1)$.
Table 18. Energy efficiency of actual heating system power and high temperature electrical heat pump heat pump power (School District 2)

\begin{tabular}{|c|c|c|c|c|}
\hline \multirow[t]{2}{*}{ School District 2} & \multicolumn{2}{|c|}{$\begin{array}{l}\text { Actual } \\
\text { heating } \\
\text { system }\end{array}$} & \multicolumn{2}{|c|}{$\begin{array}{c}\text { High } \\
\text { temperature } \\
\text { electrical heat } \\
\text { pump }\end{array}$} \\
\hline & $\begin{array}{c}\text { Power } \\
\mathrm{kW}\end{array}$ & & $\begin{array}{c}\text { Power } \\
\mathrm{kW}\end{array}$ & $\eta$ \\
\hline Technical Industrial High School & 2670 & 0.64 & 684 & 2.50 \\
\hline Technical Scientific High School & 390 & 0.83 & 129 & 2.50 \\
\hline Technical Building High School & 980 & 0.84 & 329 & 2.50 \\
\hline Total & 4040 & 0.77 & 1142 & 2.50 \\
\hline
\end{tabular}

The heating system energy savings of two School Districts is reported in table 19 .

Table 19. Energy saving after heating system improvement

\begin{tabular}{c|ccc}
$\begin{array}{c}\text { School } \\
\text { district }\end{array}$ & $\begin{array}{c}\text { Energy } \\
\text { consumption } \\
\text { after envelope } \\
\text { interventions }\end{array}$ & $\begin{array}{c}\text { Energy } \\
\text { consumption } \\
\text { after envelope } \\
\text { and heating } \\
\text { system } \\
\text { improvement } \\
\mathrm{kWh} / \text { year }\end{array}$ & $\begin{array}{c}\text { Energy } \\
\text { savings }\end{array}$ \\
\hline $\mathbf{1}$ & $\mathrm{kWh} / \mathrm{year}$ & 72434 & $\%$ \\
$\mathbf{2}$ & 538046 & 201097 & 60
\end{tabular}

The heating system actions have an added improvement of $70 \%$ for School District 1 and of $66 \%$ for School District 2.

The total energy savings of envelope and heating system improvement respect to the actual situation (nothing improvements) are $94 \%$ for School District 1 and $88 \%$ for School District 2.

Moreover, this system needs of an electrical energy power to the compressor of $245 \mathrm{~kW}$ for School District 1 and 400 $\mathrm{kW}$ for School District 2.

This solution needs the building of electrical conversion cabin with a high installation costs.

\subsection{Cogeneration system}

The third hypothesis is the installation of a unique cogeneration system.

Even this system supplies the thermal energy to the School District.

As the heating system described in paragraph 3.1, also this heating system must guarantee an energy request of 22671 scm/year for School District 1 and an energy request 56968 $\mathrm{scm} /$ year for School District 2.

The main benefit of a CHP system respect others system is its efficiency.

The global efficiency is given by the ratio of the sum of the useful thermal energy and the total electrical/mechanical energy produced and the fuel energy input into the cogeneration energy production system (see Eq. 1) [9]

$\eta=\frac{Q_{e l}+Q_{t h}}{Q_{c h}}$ 
One of the advantage of cogeneration is economic: a gooddesigned cogeneration system supplies significant energy savings of $25-40 \%$.

Energy performance is equal to $70-85 \%$, a really significant value compared to the $50-60 \%$ of the new combined cycle plants for electricity production only.

To design a CHP system, it is necessary to define:

- Climate data;

- Thermal energy needs for heating and hot water;

- Electric energy request;

- Calculation interval (month);

- Performance data of cogeneration section.

The cogeneration plant was designed on electricity consumption of the entire district. The electric consumption of the two School District is: $191861 \mathrm{kWh}_{\mathrm{el}} /$ year for School District 1 and $252802 \mathrm{kWh}_{\mathrm{el}} / \mathrm{year}$ for School District 2.

To quantify the electrical production of CHP we assumed the following hypothesis:

- The Italian school are opened from September to June (9 months) every year. In this period the school is opened for lessons 200 days in the year and we considered another 30\% (60 days) for extra-scholastic activities;

-We considered an average artificial lighting on of 5 hours.

The total hours of artificial lighting on are 1300 in one year.

The cogeneration power for School District 1 has $63 \mathrm{kWh}_{\mathrm{el}}$ with an energy efficiency of $31.50 \%$ and $111 \mathrm{kWh}_{\text {th }}$ with an energy efficiency of $55.50 \%$.

For School District 2 the cogeneration power has 165 $\mathrm{kWh}_{\mathrm{el}}$ with an energy efficiency of $31.5 \%$ and $291 \mathrm{kWh}_{\text {th }}$ with an energy efficiency of $55.5 \%$.

Table 20. Thermal and electric production of CHP for the two School District

\begin{tabular}{c|cc} 
School Districts & $\begin{array}{c}\text { Thermal Production } \\
\mathrm{kWh}_{\mathrm{th}} / \mathrm{year}\end{array}$ & $\begin{array}{c}\text { Electric Production } \\
\mathrm{kWh}_{\mathrm{e}} / \mathrm{year}\end{array}$ \\
\hline $\mathbf{1}$ & 144300 & 81900 \\
$\mathbf{2}$ & 378300 & 214500
\end{tabular}

For School District 1 the electric request is covered for $55 \%$; while for School district 2 this percentage is equal to $91 \%$.

Thanks to the reduction of energy requirement, the cogeneration system is allowed to cover heating energy demand most of the heating period.

\section{CONCLUSIONS}

The analysis conducted on the two School Districts has demonstrated the behaviour of three different heating systems used to analyse two different School Districts.

The heating system analysed were:

- High temperature absorption heat pump integrated with a solar thermal system;

- High temperature electrical heat pump;

- Cogeneration system.

The best energy efficiency of high temperature electrical heat pump allow an energy saving of 28 percentage points for School District 1 and 26 percentage points for School District 2 respect to the installation of high temperature absorption heat pump.
If we consider the total energy savings of envelope and heating system improvement respect to the actual situation (nothing improvements) these percentage different between the absorption heat pump and electrical heat pump became 6\% for School District 1 and 10\% for School District 2 .

The use of CHP system allows to reduce electrical consumption and thermal consumption. For both School Districts this solution reset the heating consumption; while reduce the $55 \%$ of electric consumption for School District 1 and the $91 \%$ of electric consumption for School District 2.

From energy point of view the CHP system analysed is the best solution.

In term of primary energy, the three solutions has a different environmental impact as reported in following Table 21.

Table 21. Primary energy of School Districts

\begin{tabular}{c|ccc}
$\begin{array}{c}\text { School } \\
\text { District }\end{array}$ & $\begin{array}{c}\text { Absorption } \\
\text { heat pump } \\
\text { kWh }\end{array}$ & $\begin{array}{c}\text { Electrical } \\
\text { heat pump } \\
\text { kWh }\end{array}$ & CHP \\
\hline 1 & 133791 & 141247 & kWh \\
2 & 371389 & 392139 & 668850
\end{tabular}

This study analysed energy strategies which can became driver for the next replicability of the intervention proposed in other similar contexts, since it is configured as a reference criterion, applicable to almost all of the public buildings belonging to the national heritage.

The hypothesis of a unique installation for several buildings stands as a starting point for a proposal for reduction of energy consumption that unifies and reduces the number of thermal plants currently present.

This would allow, thanks to the innovative generation systems, to reduce demand for primary energy and lower maintenance costs borne by the Public Administration.

These actions, in addition to providing solutions to the needs of management optimization of the buildings, also meet the transposition duties of current European and National legislation.

\section{ACKNOWLEDGMENT}

The work was realized within the FESTA project (Fostering local energy investments in the Province of Matera), financed by European Union's Horizon 2020 research and innovation programme under grant agreement No 649956.

\section{REFERENCES}

[1] Ugur Ç., Kemal Ç., Fikret Y. (2012). The role of cogeneration systems in sustainability of energy, Energy Conversion and Management, Vol. 63, pp. 196-202.

[2] Burer M., Tanaka K., Favrat D., Yamada K. (2003). Multi-criteria optimization of a district cogeneration plant integrating a solid oxide fuel cell-gas turbine combined cycle, Heat Pumps and Chillers, Energy, Vol. 28, pp. 497-518.

[3] Gambarotta A., Vaja I. (2003). La cogenerazione: produzione combinata di elettricità e calore" in the "La Cogenerazione", Agency for Energy Savings, Ancona, Italy, Vol. 1, No. 1, p. 3. 
[4] Barbieri E.S., Spina P.R., Venturini M. (2012). Analysis of innovative micro-CHP systems to meet household energy demands, Apply Energy, Vol. 97, pp. 723-733.

[5] Zywica G., Turzynski T. (2017). Experimental investigation of the domestic CHP ORC system in transient operating conditions, Energy Procedia, Vol. 129, pp. 637-643.

[6] Pei G., Li J., Li Y., Wang D., Ji J. (2011). Construction and dynamic test of a small-scale organic Rankine cycle, Energy, Vol. 36, pp. 3215-3223.

[7] Chen X.P., Wang Y.D., Yu H.D., Wu D.W., Li Y., Roskilly A.P. (2012). A domestic CHP system with hybrid electrical energy storage, Energy and Buildings, Vol. 55, pp. 361-368.

[8] Maraver D., Sin A., Royo J., Sebastián F. (2013). Assessment of CCHP systems based on biomass combustion for small-scale applications through a review of the technology and analysis of energy efficiency parameters, Appl Energ, Vol. 102, pp. 1303-1313.

[9] Cammarata G., Cammarata M., D’Amico G., Russo F. (2013). Integrazione degli impianti meccanici-La Cogenerazione", in Edifici ad energia quasi zero, Grafill, Vol. 9, No. 9\&10, pp. 323-333.

[10] Rospi G., Negro E., Cardinale N. (2017). Design of small cogeneration system for public buildings in the town of Matera, International Journal of Heat and Technology, Vol. 34, DOI: 0.18280/ijht.35Sp01XX

[11] Italian Law $n^{\circ} 373 / 76$, Official Gazette, No.148, del 7 6-1976

[12] Italian Law $n^{\circ}$ 10/91. Official Gazette, No. 13, del 161-1991 - Ordinary Suppl. n. 6

[13] Thermal insulation -- Building elements - In situ measurement of thermal resistance and thermal transmittance, (2014). ISO 9869-1.

[14] Rospi G., Cardinale N., Intini F., Negro E. (2017). Analysis of the energy performance strategies of school buildings sitein the Mediterranean climate: A case study the schools of Matera city, Energy and Buildings, Vol. 152, pp. 52-60.

[15] Building components and building elements -Thermal resistance and thermal transmittance Calculation method. (2008). UNI EN ISO 6946.

[16] Thermal performance of windows, doors and shutters -- Calculation of thermal transmittance. (2012). UNI EN ISO 10077 1-2.

[17] U.S. Department of Energy's (DOE) Building Technologies Office (BTO) Energy Plus, from: https://energyplus.net/downloads

[18] Interministerial Italian Decrees 26. (2015). Decree for minimum requirements: application of the calculation methodology of the energy performance and definition of requirements and minimum requirements for buildings, GU, No. 162, of 15-7-2015 - Ordinary Suppl. No. 39.

\section{NOMENCLATURE}

$\eta$

$Q_{e l}$

$Q_{\text {th }}$

$Q_{c h}$ $\lambda$

$\mathrm{U}$
Global energy performance, dimensionless Fuel energy converted into electricity, $\mathrm{kWh}_{\mathrm{el}}$ Fuel energy converted into heat, $\mathrm{kWh}_{\text {th }}$ Energy given by fuel, $\mathrm{kWh}_{\text {th }}$ Thermal conductivity, $\mathrm{W} / \mathrm{mK}$ Thermal trasmittance, $\mathrm{W} / \mathrm{m}^{2} \mathrm{~K}$ 